\title{
Theoretical strengthening of the concept of appealing in analysed sermons on Matthew 25:31-46 in the context of poverty in South Africa
}

\author{
Author: \\ Hennie J.C. Pieterse ${ }^{1}$ \\ Affiliation: \\ ${ }^{1}$ Department of Philosophy, \\ Practical and Systematic \\ Theology, UNISA, \\ South Africa \\ Correspondence to: \\ Hennie Pieterse \\ Email: \\ pietehjc@absamail.co.za \\ Postal address: \\ 262 Marais street, Brooklyn \\ 0181, South Africa \\ Dates: \\ Received: 10 Jan. 2013 \\ Accepted: 03 June 2013 \\ Published: 06 Aug. 2013 \\ How to cite this article: \\ Pieterse, H.J.C., 2013, \\ 'Theoretical strengthening \\ of the concept of appealing \\ in analysed sermons on \\ Matthew 25:31-46 in the \\ context of poverty in South \\ Africa', In die Skriflig/In \\ Luce Verbi 47(1), Art. \#692, \\ 8 pages. http://dx.doi. \\ org/10.4102/ids.v47i1.692 \\ Note: \\ This article is part of \\ project being conducted \\ with the financial support \\ of the National Research \\ Foundation.

\section{Copyright:} \\ (C) 2013. The Authors. \\ Licensee: AOSIS \\ OpenJournals. This work \\ is licensed under the \\ Creative Commons \\ Attribution License. \\ Read online:

Scan this QR
code with your
smart phone or
mobile device
to read online.

From a qualitative grounded theory analysis in a sample of 26 sermons with Matthew 25:3146 as sermon text, a rhetorical structure of how the preachers try to convince their listeners to care for the poor emerged. The homiletical concept of appealing related to all the categories borne out of the analysis of the inner world of the 26 sermons, and also to the categories showing this rhetorical structure in the sermons. The article discusses what the dimensions are in the concept of appealing borne out of the sermons in which the rhetorical structure was apparent, which rhetorical theory would fit as theoretical base for the concept of appealing in its relationship with the rhetorical structure in the sermons, and what dilemma the preachers face when they try to convince their listeners to participate in the care for the poor. The rhetorical theory of deliberative rhetoric (Aristotle) and the classical theory with the three dimensions logos, ethos and pathosis discussed in this article as theoretical thickening of the concept of appealing to the listeners of the sermons. This article attempts to demonstrate how to go about theorising from a grounded theory analysis of sermons with Matthew 25:31-46 as a sermon text with, as result, a theory that could help preachers in preaching from this text in the context of poverty in South Africa.

Teoretiese versterking van die konsep appèl in geanaliseerde preke oor Matteus 25:31-46 in die konteks van armoede in Suid-Afrika. Vanuit ' $n$ kwalitatief-gegronde teorie-ontleding (grounded theory analysis) van 26 preke met Matteus 25:31-46 as preekteks, het 'n retoriese struktuur na vore gekom waarmee predikers hulle toehoorders wil oorreed om armes te versorg. Die homiletiese konsep van appèl, hou verband met al die kategorieë wat uit die inhoudsanalise van die binnewêreld van die 26 preke na vore gekom het, asook die kategorieë waarin die retoriese struktuur sigbaar is. Die artikel bespreek die dimensies in die konsep van appèl wat na vore kom uit die preke waarin die retoriese struktuur duidelik is, welke retoriese teorie as teoretiese basis kan dien vir die konsep van appèl in verband met die retoriese struktuur in die preke, asook teenoor welke dilemma die predikers te staan kom wanneer hulle probeer om hulle hoorders te oorreed om vir armes te versorg. Die deliberatiewe retoriese teorie van Aristoteles en die klassieke teorie met die dimensies logos, etos en pathos word in die artikel bespreek as teoretiese versterking vir die konsep van appèl op die toehoorders van die preek. Die artikel poog om aan te toon hoe ' $n$ mens teoretisering vanuit ' $n$ gegronde teorie-ontleding van preke met Matteus 25:31-46 as preekteks kan aanpak, met as resultaat, 'n teorie waarmee predikers gehelp word om in die armoedekonteks van Suid-Afrika te preek.

\section{Introduction}

The theological approach for preaching that is been followed in this article in discussing the concept of appealing to or calling on the congregation members is according to the homiletical insights of the Reformers from the sixteenth century. John Calvin sees preaching as the exegesis and proclamation of the sermon text from the Bible as the Word of God (Immink 2005:285). In this process, the work of the Holy Spirit is decisive. Scripture is God's Word in human language, inspired by the Spirit, and when we read and preach it in a prayerful and humble way, open to God's message for us, the Spirit enlightens our mind and hearts to understand the Word for our own context (Calvijn 1956:42-50; De Klerk \& Van Rensburg 2005:4, 12). Therefore, preacher and congregation have to pray for the guidance and enlightenment by the Holy Spirit. This is being done in the liturgy before the sermon in the epiklese prayer. The Holy Spirit also inspires the members of the congregation to live the message of the sermon everyday by means of the Word of God being heard in the sermon, which inspires and motivates them to act according to the message.

In this article, I intend to theoretically discuss the concept of appealing, which is the emerging central concept in my content analysis of sermons on poverty, as well as in the theory of preaching 
on Matthew 25:31-46 in the South African context of poverty. This article is therefore the result of the third cycle of grounded theory research, namely the theoretical coding cycle.

\section{Explaining the grounded theory approach}

I worked with a grounded theory analysis of sermons in my research project of five years (cf. Pieterse 2010 for a description of grounded theory analysis of sermons). The grounded theory approach, developed in sociology (cf. Glaser 1978, 1998; Charmaz 2006), has been applied in empirical homiletics by F.G. Immink's research group in Utrecht, the Netherlands, of which the first result has now been published (cf. Pleizier 2010).

The process of grounded theory analysis of sermons develops in a bottom-up approach in three cycles:

- Open coding as an inductive exercise, initial identifying of categories and the development of an open coding analytical model.

- Selective coding, that is, a deductive exercise in which sermons are selectively chosen for analysis on the basis of the hypotheses that are developed in the open coding analytical model.
- Theoretical coding and the construction of a theory of preaching on the theme of the analysis.

\section{Background data of preachers participating in sample}

From a qualitative grounded theory analysis on a sample of 26 sermons (across 8 provinces in South Africa) with Matthew 25:31-46 as sermon text, a rhetorical structure has emerged of how the preachers try to convince their listeners to care for the poor (cf. Pieterse 2011, 2012). These sermons are from a sample of 12 preachers from the Uniting Reformed Church (URC) and 14 sermons from the Dutch Reformed Church (DRC), [Nederduitse Gereformeerde Kerk]. I used a theoretical sample by asking my ex-doctoral students, who are working in congregations in all the provinces of South Africa, to identify preachers in their province whom I may approach for a typed or written text of the sermon (cf. Swinton \& Mowat 2006:69). The tables that follow provide the demographics of the 26 preachers who participated in the first and second cycle of the analysis:

In the research, I addressed the problem of how to preach in the South African context of poverty by means of an empirical

TABLE 1a: Preachers participating in the first cycle.

\begin{tabular}{|c|c|c|c|c|c|}
\hline Name & Denomination & Gender & Age Group & Education & Province \\
\hline Preacher A & URC & M & Elderly & High & Mpumalanga \\
\hline Preacher B & URC & M & Middle & Middle & Gauteng \\
\hline Preacher C & URC & $\mathrm{F}$ & Middle & Middle & Limpopo \\
\hline Preacher D & URC & $M$ & Elderly & High & Eastern Cape \\
\hline Preacher E & URC & $M$ & Elderly & Middle & Eastern Cape \\
\hline Preacher F & URC & $M$ & Young & Middle & Eastern Cape \\
\hline Preacher G & DRC & $M$ & Middle & Middle & North West \\
\hline Preacher $\mathrm{H}$ & DRC & $M$ & Young & Middle & Gauteng \\
\hline Preacher I & DRC & M & Young & Middle & Gauteng \\
\hline Preacher J & DRC & M & Middle & High & Limpopo \\
\hline Preacher K & DRC & $\mathrm{F}$ & Young & Middle & Mpumalanga \\
\hline Preacher L & DRC & $\mathrm{F}$ & Young & Middle & Gauteng \\
\hline
\end{tabular}

URC, Uniting Reformed Church; DRC, Dutch Reformed Church.

F, female; $M$, Male.

Age in years: Young, 25-39; Middle, 40-55; Elderly, 56 +

Education: Middle, normal theological training for the ministry; High, holder of a doctor's degree.

TABLE 1b: Preachers participating in the second cycle.

\begin{tabular}{|c|c|c|c|c|c|}
\hline Name & Denomination & Gender & Age Group & Education & Province \\
\hline Preacher $\mathrm{P}$ & URC & $M$ & Middle & High & Western Cape \\
\hline Preacher Q & URC & $M$ & Middle & Middle & Eastern Cape \\
\hline Preacher R & URC & $M$ & Elderly & Middle & Eastern Cape \\
\hline Preacher S & URC & M & Middle & Middle & Eastern Cape \\
\hline Preacher $\mathrm{T}$ & URC & M & Young & Middle & Kwazulu-Natal \\
\hline Preacher U & URC & $M$ & Middle & Middle & Gauteng \\
\hline Preacher M & DRC & M & Middle & High & Kwazulu-Natal \\
\hline Preacher $\mathrm{N}$ & DRC & $M$ & Young & Middle & Gauteng \\
\hline Preacher 0 & DRC & $M$ & Young & Middle & Mpumalanga \\
\hline Preacher V & DRC & M & Young & High & Gauteng \\
\hline Preacher W & DRC & $M$ & Middle & High & North-West \\
\hline Preacher X & DRC & $M$ & Elderly & Middle & Free State \\
\hline Preacher $Y$ & DRC & $M$ & Middle & High & Western Cape \\
\hline Preacher Z & DRC & $M$ & Middle & High & Gauteng \\
\hline
\end{tabular}

URC, Uniting Reformed Church; DRC, Dutch Reformed Church.

F, female; M, Male.

Age in years: Young, 25-39; Middle, 40-55; Elderly, $56+$.

Education: Middle, normal theological training for the ministry; High, holder of a doctor's degree. 
homiletical study. I decided to take Matthew 25:31-46 as a sermon text in order to be able to preach in the poverty conditions of South Africa. The leading research question of this project is: How do preachers deal with sermons on poverty with Matthew 25:31-46 as sermon text? The research was conducted with a grounded theory methodology as applied to homiletics (Pleizier 2010:16-21, 99-100). This method comprises of three cycles of research, namely an open coding cycle (Pieterse 2011), a selective coding cycle (Pieterse 2012) and a theoretical coding cycle, on which this article reports. In this research process, a theory is systematically developed from practice to theory.

The homiletical concept of appealing relates to all the categories borne out of the two cycles of analysis in the inner world of the 26 sermons, namely the open coding cycle and the selected coding cycle (cf. Pieterse 2011, 2012). Therefore, it is regarded as the central concept that emerged from the analysed sermons. In this concept there is a rhetorical structure that falls out in three dimensions, as we will discuss in this article. The concept of appealing was enriched in the second cycle of coding with a new phrasing of calling on the listeners to participate in the congregational projects directed to the poor, which is indicated as central concept (see Figure 1 below) of the theoretical framework in this article (cf. Pieterse 2013).There is a dilemma in this enriched concept of calling on the listeners, which will also be discussed.

The rhetorical structure in the concept of appealing or calling with a rhetorical theory in a theorising process will be strengthened, the dimensions in the central concept of appealing or calling will be discussed, and a rhetorical theory for the dilemma in the concept of calling on the listeners to participate in the congregational projects directed to the poor will be developed. Then the concepts of exegesis of Matthew 25:31-46 will be summerised. It relates to the central concept, and the typology of congregational projects directed to the poor, which also relates to the central concept. Both of these concepts form part of the theory of preaching on poverty

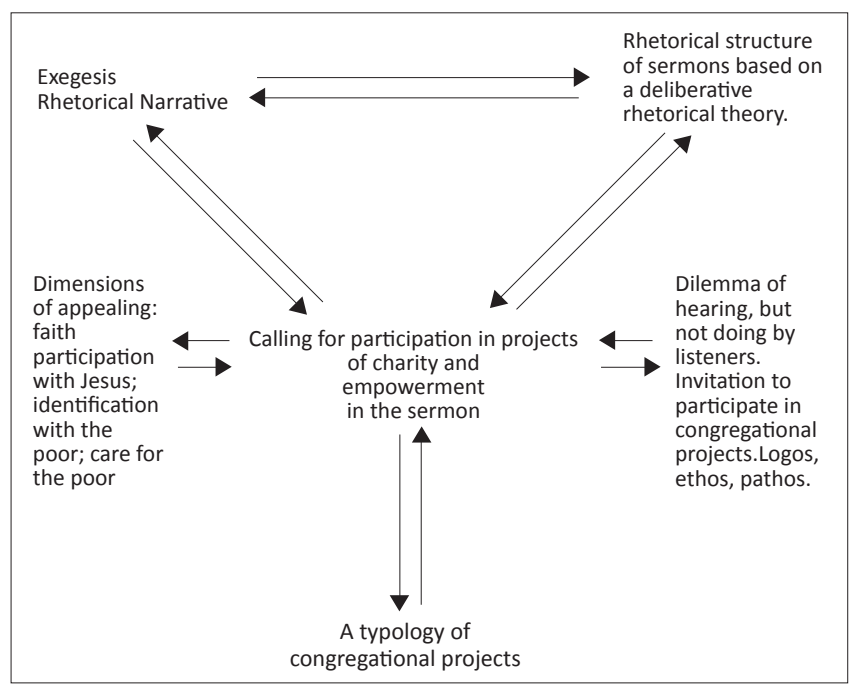

Source: Author's own research

FIGURE 1: An emerging theory of preaching on Matthew 25:31-46 in the context of South Africa. from this biblical text in South Africa as indicated in Figure 1 of the theoretical framework.

\section{The rhetorical structure in the sermons as a concept in the theoretical framework}

This rhetorical structure already emerged from the 12 sermons analysed in the first cycle of open coding analysis. It was also the case in the new collection of 14 sermons analysed in the second cycle of selective coding. From the question 'What are the preachers doing in these sermons?', the following pattern emerged: preachers are appealing to the hearers of the sermon by employing their faith participation with Jesus in order to appeal to them to choose to identify with the poor and humble as Jesus did and then appealing to them to, as followers of Jesus, care for the poor and humble in the present context of the congregations in South Africa. This pattern is clear from the categories that emerged from the sermons. It is a pattern with a dimension of consequence (cf. Pieterse 2011:107-108).

Three categories emerged from the open coding content analysis of the first 12 sermons, namely:

- Faith participation with Jesus.

- The followers of Jesus identifying with the poor.

- Caring for the poor in present-day congregations.

All three categories are linked and connected by the idea of how the preachers go about in appealing to the listeners, which can be conceptualised as consequence (Pieterse 2011:107). On a theoretical level, this is a rhetorical structure that functions as a concept in the theory of preaching on poverty in South Africa from Matthew 25:31-46 as sermon text (see the concept at the top on the right-hand-side in Figure 1). Sermons are built on the exegesis of the sermon text. Therefore, a summary of the rhetorical exegesis on this sermon text is been provided, as well as a narrative exegesis from the perspective of homiletics.

\section{Exegesis of Matthew 25:31-46 as a concept in the theoretical framework}

Where did the preachers find this rhetorical structure? A rhetorical exegesis of this text (Mt. 25:36-41) gives an indication. An academic exegesis of this text is not been done beforehand on purpose, because I wanted to be openminded of what will emerge from the sermons. Therefore, the exegesis of this text is been done at the end of the analysis of all the sermons in the two cycles - only in the third cycle of theoretical coding.

The new rhetoric of Perelman and Olbrechts-Tyteca (1969), as Vorster (2009) applied it to New Testament exegesis, opens a window on how consequences in argumentation work and affect persuasion (Vorster ibid):

Consequences are not neutral entities, they are infused with values, they carry weight. The weight they carry were given to them by the society on which they functioned over a lengthy period of time. (p. 507) 
Perelman and Olbrechts-Tyteca (1969:263-292) work with the concept of a sequential-reality structure argument. The acts of characters in an argumentation have consequences. In Matthew 25:31-46, the acts of those who have given food and care for the 'least of my brothers' have cared for Jesus himself, and the consequence is that the King will tell them when all the nations have gathered before him on judgment day: 'You have my Father's blessing; come, enter, and possess the kingdom that has been ready for you since the world was made' (Mt 25:34). The acts of those who did not care for the poor and humble have a negative consequence on judgment day. The preachers used this deep relationship between Jesus and the poor and humble to make the first move in their sermon argument, namely the listeners' faith participation with Jesus, in order to argue that we should also identify with the poor and humble as Jesus did, followed up by the argument of consequence. Therefore, they call on the listeners to care for the poor as Jesus did.

\section{An oration with three layers of meaning}

This text can be seen as an oration (Van der Ven 1998:365-378). Matthew 25:31-46 gives a deeper meaning to the neighbour to whom charity is done. This oration has three layers of meaning: a moral, a theological and an eschatological layer.

The moral layer of meaning consists of the appeal to, or calling on, the people to change the status quo of social relations. How important the rules of acting towards people in need are, it is not as important as the reaction of people when they look a destitute person in the eye. This oration not only tells us who my neighbour is, but also what adequate charity is. The six groups of suffering people, with the classical biblical personae miserae of widows, orphans and poor, represent the whole of suffering people of all times. We will be judged by our care for people in need: 'anything you did for these least brothers of mine, you did it for me' (Mt 25:40). The morality of the text does not lie in a moral imperative, but in an appeal to break through the conventional norms of care.

The theological layer of this oration consists of the identification of Jesus with these humble and suffering people.

The eschatological layer consists of the fact that we will not know here and now to whom charity is done, nor by whom. What true and adequate charity is, will only be revealed on the last day - the judgement day (Van der Ven 1998:365-378).

\section{Reading Matthew as a narrative}

From the perspective of a narrative exegesis of this text, some important aspects have been addressed. Matthew 25:31-46 forms part of the wider context of chapters 23 to 25 , which form the fifth and last discourse of Jesus in the Gospel of Matthew. Matthew 24 and 25 address the signs of the times, the vigilance while waiting for the parousia, and the second coming of Jesus (Combrink 1987:69-70). We can also read Matthew as a narrative and view the parables as metaphors (Van Aarde 1994:236-240; Combrink 1987:69, 1991:2), and indeed as diaphoric metaphors (Reinstorf \& Van Aarde
1998:609). The gist of these chapters is a confrontation with the demands of the kingdom of God, to be vigilant while waiting for the parousia in daily living and practicing the gifts of the kingdom of God: love and mercy (Combrink 1987:71; Jones 1995:481).

An important question for the perspective of this article is: Does the expression 'for one of the least of these my brothers' (eni toutoon toon adelphoon mou toon elachistoon) refer to all the poor and needy, to Christian missionaries, or to all Christians (Snodgrass 2008:555)? Snodgrass approaches the problem from the viewpoint that the issue here is the purpose of the parabolic saying and its explanation in Matthew 25:31-46. 'Are they and their placement in Matthew intended to console threatened Christians ... or to motivate faithful discipleship marked by mercy and love?' (Snodgrass ibid:557). He chooses the latter as the purpose because of the context and the concerns of Jesus and Matthew. The teaching of Jesus and his gospel focuses on mercy and love. Entrance into the kingdom is based on doing the will of the Father (Mt 7:21-23). Therefore Snodgrass (ibid:557) states that 'these least brothers of mine [must] be understood generally of those in need'.

Van Aarde (2008:540) agrees with Weren (1979:188-190) that Matthew focuses on the ethics of care for the poorest of the poor with reference to Matthew 25:45 - the hoi elachistoi. The six works of love are ethical activities that must be practiced every day in every era, with an unexpected dimension in it, because the Son of Man is in solidarity with those in need and views them as his brothers (Weren ibid:115). This is the novum in comparison with apocalyptic literature in the answer of the 'when' of the paroesia and the coming of the kingdom of God (Weren ibid:115). Matthew's eschatology functions as a continuing present perspective (Weren ibid:190). The gifts of the Kingdom of God are love and mercy and these are universal and fundamental (Jones 1995:481). A narrative exegesis of this text therefore also indicates that the text could be interpreted as a universal appeal. All 26 of the preachers in this research project interpreted the text in this sense - thus also for contemporary South Africa.

\section{A deliberative rhetorical theory}

Although the exegesis in this article forms a separate concept in the developing theory, it is related to the rhetorical structure as a concept in the theory, as well as to the concept of appealing, thickened to 'calling for participation in projects of charity and empowerment in the sermon', as the central concept in the theory (see Figure 1). To strengthen this rhetorical structure theoretically, we need to fit it with a rhetorical theory. I have chosen the deliberative rhetorical theory of Aristotle.

\section{Practical reason}

If practical theologians want to work with a public practical theology in order to participate in discourses with other social and human disciplines on public issues (cf. Dreyer 2008), we need to choose rhetorical theories with which we 
can argue in public reason with credibility. In the case of this research project on the church's role in addressing poverty in South Africa, the deliberative rhetorical theory of Aristotle is suitable (Van der Ven 2010:25). This rhetoric works with rationality (cf. Van der Horst 2003). Deliberative rhetoric does not work within theoretical reason, but within practical reason (Van der Ven ibid:25). From the perspective of Habermas' interpretation (cf. Habermas 1984, 1989), theoretical reason refers to the question of how the physical, social and psychical world looks like and how scientific interventions in this world are effective. Practical reason refers to the question how we have to act in the world, and which norms and values, as well as reasons justify our human actions. Therefore, we have to distinguish between theoretical and practical arguments. Practical reason has to do with communicative actions. Practical reason in practical theology refers to the question of religious justification of values and norms in our communicative actions. The contextual situation in which we act plays an important part in the qualification of values, norms and reasons for our communicative actions.

\section{Deliberative argumentation}

Deliberative argumentation in the domain of practical reason is dialogical. There are multiple perspectives in the public arena of discourses. Therefore, practical theologians need to see and understand other perspectives than their own. We should not only take external critique of our perspectives and arguments into consideration, but also internal religious critique. Contra-arguments and own arguments must prosper in a space of freedom and respect. Arguments and new insights can be strengthened in such a discourse.

Preaching is dialogical. The perspectives of the Biblical text and those of contemporary listeners are constantly in dialogue and confrontation. Deliberative argumentation is suitable when we want to participate with practical theological results in public discourse. In argumentation we take a specific perspective, argue logically, take other perspectives inconsideration and come to conclusions, which are supported by valid arguments (Van der Ven 2010:28).

In a deliberative rhetorical theory with deliberative argumentation, one should seek common ground and be ready to compromise in order to come to insights that can take one further in addressing public problematic issues.

With this deliberative rhetorical theory, the concept of the rhetorical structure of sermons in order to convince the congregation to care for the poor in South Africa, can be theoretically strengthened.

The sermon is a form of a public address. We are dealing with interaction - dialogue between speaker and hearer (Immink 2005:274). A sermon is essentially dialogue - between the message of the biblical text and the hearers of the sermon, with the preacher as mediator. Rhetoric has always played a significant role in homiletics (Immink ibid:273). Therefore, a deliberative rhetorical theory is suitable for the theoretical strengthening of the preacher's appeal or call in a sermon to the listeners.

\section{Dimensions in the concept of appealing as a concept in the theoretical framework}

During the qualitative content analysis of the first 12 sermons in the cycle of open coding, a clear pattern in the variation of dimensions in the emerging concept of appealing became clear. This pattern of dimensions also emerged from the following 14 sermons collected in the second cycle of selective coding. These are the dimensions of faith participation with Jesus by preacher and congregation; identification with the poor by Jesus and therefore also by the congregation. Also care for the poor by Jesus as witnessed in the gospels, and therefore the preachers' call on the congregation to also care for the poor.

Three categories of the contents of the sermons emerged from the analysis of the sermons, namely:

- Category 1: Faith participation with Jesus;

- Category 2: Identifying of the followers of Jesus with the poor; and

- Category 3: Caring for the poor and humble by presentday congregations.

The concept of appealing relates to all three categories. All three categories, in conceptualised phrasing, represent the three dimensions in the concept of appealing.

The idea of preachers appealing on the faith participation with Jesus in order to preach the message from the text and appeal to the listeners to choose taking up the great task of the congregation in caring for the poor and humble, also forms a consequence of appealing as a link between the initial categories.

\section{The dilemma for preachers of the listeners hearing, but not doing as a concept in the theoretical framework}

In the cycle of selective coding where 14 sermons in congregations with projects directed at helping the poor were analysed, the preachers invite their listeners to participate in these projects that the congregations are running. The fact that they are invited to participate shows a dilemma in this calling in the minds of the preachers: listeners who hear the appeal, but are not doing it.

The classical rhetorical theory with three dimensions of logos, ethos and pathos, strengthens this concept of the dilemma of preachers with people hearing the call, but not doing it (cf. Lambrecht 1989:240; Vos 1996:164-166). We see rhetoric in a communicative frame in homiletics. It opens up new possibilities to understanding and knowledge, but it can also hide reality (Vorster 1994:470-477). Preachers should handle it with care. 
Logos has to do with the logical structure of the sermon. The rhetorical structure in the sermons following the consequences of our caring for the poor and humble in the biblical text, show that the preachers have handled this dimension well.

A positive image in the minds of the listeners in the sermon describes the dimension of ethos in this theory. This makes it possible for them to identify with the preacher. The members of the congregation experience the preachers as honest, reliable people who are in solidarity with them, care for them and have their interests at heart. It requires working at relationships between preacher and members of the congregation. In all the congregations I have researched, the preachers have been working there for long periods. This is obviously not the place for a dilemma in their communication with the listeners.

Pathos in this theory means a strong, emotional relationship between the preacher and the listeners. If a preacher fails to communicate on an emotional level, there can be no real persuasion or identification. It is in the dimension of pathos where I could detect the dilemma of hearing, but not doing. Preachers plead with them in their invitations to participate in the projects. Two examples demonstrate this:

I want to ask you: [have you] developed a hardness of [heart] towards people in need around us? Do you have an uncharitable mind and are you untouched by the need of people? May God through his Spirit help you to become a [heart] full of love and compassion. I invite you to participate in our projects with commitment. (Preacher V)

I want to invite you to move with us and to become involved in the projects of the congregation. If the sermon gives you an uncomfortable feeling, it is good. The words of Jesus want to give you hope for the future that we can do something in his Name for those in need. Make your choice this morning. (Preacher N)

In grounded theory research, one has to look for dimensions and dilemmas in the central concept with a view on strengthening it theoretically (Pleizier 2010:146-147). It also came to the surface in the analysis of the sermons in this research project.

\section{A typology of congregational projects directed to the poor as a concept in the theoretical framework}

The question of why church members get involved in projects directed to the poor is important. Here the idea of religious motivation (Christian faith actions inspired by the sermon message) is an explanation for their actions. Ronald Jeurissen works with religious motivation in his research on peace and religion. He argues that the function of the Christian proclamationis essentially is a motivational one (Jeurissen 1993:62). The proclamation of God's creation, salvation and completion of the world motivates to moral action by putting the Christian believer in a new context of meaning, which summons him to a responsible partnership with God the Creator. Church members are doing it in our context, regardless of ethnicity - there are projects to poor Black and White people. A great variety of projects emerged from the sermons. The different types of projects were arranged in a typology of projects (Pieterse 2012).

\section{Main category I: Projects of charity by congregations}

\section{Subcategory I A}

Food provision:

- The congregation provides food for mine workers when a mine does not function as a result of bad management. Property: Food provision for mine workers not being paid.

- The congregation provides food for jobless people waiting in the street for piece jobs.

Property: Food provision for jobless people waiting to be employed.

- Congregations provide food for poor learners at schools. Property: Food provision for learners.

- The congregation provides food for a poor community. Property: Food provision for a community.

- The congregation provides food for a home for disabled adults.

Property: Food provision for a home as an institution.

- The congregation provides food for families. Property: Food provision for families.

- The congregation provides food in a squatter camp. Property: Food provision in a squatter camp.

- Congregation members cultivate small vegetable gardens and bring the crop to the church where it is disseminated to the poor.

Property: Vegetables grown for the poor in congregation members' gardens.

\section{Subcategory I B}

Clothes provision:

- The congregation provides clothes for a poor community. Property: Clothes provision for a community.

- The congregation provides clothes for families in need. Property: Clothes provision for families.

\section{Main category II: Projects of empowerment Subcategory II A}

Relationships with the poor:

- Congregations form relationships of love, compassion and respect with the poor.

Property: Relationships of love, compassion and respect.

- Congregations form relationships of mercy and care with the poor.

Property: Relationships of mercy and care.

- Congregation forms relationships of prayer with taxi drivers and passengers during Passover. Property: Relationships of prayer.

- Congregations form relationships to solve poor people's problems.

Property: Relationships of problem-solving. 


\section{Subcategory II B}

Financial support:

- Congregations provide financial support to poor inhabitants of old age homes.

Property: Financial support for people in old age homes.

- Congregations provide financial support for the training of pastors in poor communities.

Property: Financial support for training of pastors in poor communities.

- Congregations provide financial support for the salaries of pastors and missionaries.

Property: Financial support for pastors and missionaries.

\section{Subcategory II C}

Medical support:

- Congregations provide help in preparation of medicine at state clinics.

Property: Medical support at state clinics.

- Congregations provide voluntary nurses for sick people in congregation.

Property: Medical support for people in congregation.

\section{Subcategory II D}

Educational support:

- Congregations provide money and food for poor learners in nursery, primary and high schools.

Property: Educational support for nursery, primary and high schools.

- Congregations provide money, clothes and food for orphans in children's homes.

Property: Educational support for orphans in children's homes.

\section{Subcategory II E}

Building support:

- Congregations provide help to build houses in institutions of rehabilitation.

Property: Building support in institutions of rehabilitation.

- Congregations provide helpers for the building of houses and starting of vegetable gardens to care for orphans.

Property: Building support in housing for orphans.

- Congregations provide helpers in establishing a bakery and manufacturing crafts for poor people.

Property: Building support for a bakery and crafts manufacturing.

\section{Subcategory II F}

Self-help support:

- Congregations provide helpers to train women to sew, make blankets and necklaces to sell.

Property: Self-help training for the manufacturing of goods for sale.

- Congregations provide helpers to teach women to read and write.

Property: Self-help teaching to read and write.
- The congregation has an academy at a dam in the vicinity to develop rowing and swimming skills in poor children with the purpose to develop self-discipline and a positive view of the self.

Property: Developing rowing and swimming skills for the general development of children.

- The congregation has therapeutic professionals who work with trauma experiences and healing.

Property: Professional help in situations of trauma.

- The congregation provides sun-generated electricity to poor residents with high school children in a squatter camp to help education and development.

Property: Self-help support for educational and general development.

- Congregations provide skills training to poor people in leadership and entrepreneurship, plus seed money to start own business - in 2011 there were already eight successful businesses up and running.

Property: Training and seed money to start own business.

Although many congregations run the same kind of projects, they do not overlap, because each one takes place in the immediate context of the specific congregation. These types of categories of projects by congregations in their outreach to the poor, inspired by preaching on the text from Matthew 25:31-46, bring something new into homiletical literature on preaching to the poor. My survey of the literature in 2009 has shown that homiletical literature is calling for preaching on poverty, but does not clearly say how to preach on poverty.

\section{Conclusion}

In this article, the rhetorical structure in the concept of appealing was strengthened with a rhetorical theory in a theorising process in the third cycle of grounded theory analysis of sermons. The dimensions in the central concept of appealing were discussed, and a rhetorical theory for the dilemma in the concept of calling on the listeners to participate in the congregational projects directed to the poor were developed. Thereafter, the concept of exegesis of Matthew 25:31-46 which relates to the central concept were summarised, as well as the typology of congregational projects directed to the poor, which also relates to the central concept. The emerging theory of preaching on poverty from this biblical text in South Africa, as indicated in the theoretical framework, was presented as the result of the grounded theory content analysis of the sermons in the sample. The connection of preaching on Matthew 25:31-46 as sermon text and the inspiration thereof for church members to voluntarily participate in congregational projects as outreach to the poor, is an original outcome of the research for homiletical thought on preaching about poverty.

\section{Acknowledgements Competing interests}

The author declares that he has no financial or personal relationship that may have inappropriately influenced him in writing this article. 


\section{References}

Calvijn, J., 1956, Institutie Deel 1, transl. A. Sizoo, Meinema, Delft.

Charmaz, K., 2006, Constructing Grounded Theory. A practical guide through qualitative analysis, Sage, London.

Combrink, H.J.B., 1987,'Matteus 25:14-30', in C.W. Burger, B.A.Müller \& D.J. Smit (reds.), Riglyne vir prediking oor die gelykenisse en wonderverhale, bl. 69-82, NG Kerk-Uitgewers, Kaapstad.

Combrink, H.J.B., 1991,'Dissipelskap as die doen van God se wil in die wêreld', in J.H Roberts, W.S. Vorster, J.N. Vorster \& J.G. van der Watt (reds.), Teologie in konteks, bl. 1-31, Halfway House, Orion.

De Klerk, B.J. \& Van Rensburg, F.J., 2005, Preekgeboorte. 'n Handleiding vir gereformeerde eksegese en prediking toegepas op 1 Petrus 2:11-12, 18-25, Potchefstroomse Teologiese Publikasies, Potchefstroom.

Dreyer, J.S., 2008, 'Practical theology and human well-being: An exploration of a multidimensional model of human action as conceptual framework', Practical Theology in South Africa 23(3), 3-22.

Glaser, B.G., 1978, Theoretical sensitivity. Advances in the methodology of Grounded Theory, Sociology Press, Mill Valley, CA.

Glaser, B.G., 1998, Doing Grounded Theory. Issues and discussion, Sociology Press, Mill Valley, CA.

Habermas, J., 1984, The theory of communicative action. Reason and the rationalization of society, vol. 1, Beacon Press, Boston.

Habermas, J., 1989, The theory of communicative action. Lifeworld and system: A critique of functional reason, vol. 2, Beacon Press, Boston.

Immink, F.G., 2005, Faith. A practical theological reconstruction, Eerdmans, Grand Rapids/Cambridge.

Jeurissen, R., 1993, Peace and religion. An empirical-theological study of the motivational effects of religious peace attitudes on peace action, Kok/Deutscher Studien Verlag, Kampen/Weinheim.

Jones, I.H., 1995, The Matthew parables. A literary and historical commentary, Brill, Leiden/Boston.

Lambrecht, J., 1989, 'Rhetorical criticism and the New Testament', Tijdschrift voor filosofie en theologie 50, 239-253.

Perelman, C. \& Olbrechts-Tyteca, L., 1969, The new rhetoric: A treatise on argumentation, Notre Dame University Press, Notre Dame.

Pieterse, H.J.C., 2010, 'Grounded theory approach in sermon analysis of sermons on poverty and directed to the poor as listeners', Acta Theologica 30(2), 113-129.
Pieterse, H.J.C., 2011, 'An open coding analytical model of sermons on poverty with Matthew 25:31-46 as sermon text', Acta Theologica 31(1), 95-112. http:// dx.doi.org/10.4314/actat.v31i1.6

Pieterse, H.J.C., 2012, 'A grounded theory approach to the analysis of sermons on poverty: Congregational projects as social capital', Verbum et Ecclesia 33(1), 689. http://dx.doi.org/10.4102/ve.v33i1.689

Pieterse, H.J.C., 2013, 'An emerging grounded theory for preaching on poverty in South Africa with Matthew 25:31-46 as sermon text', Acta Theologica 33(1), 175-195.

Pleizier, T., 2010, Religious involvement in hearing sermons. A grounded theory study in empirical theology and homiletics, Eburon Academic Publishers, Delft.

Reinstorf, D. \& Van Aarde, A.G., 1998, 'Jesus' kingdom parables as metaphorical stories: A challenge to a conventional worldview', HTS Teologiese Studies/ Theological Studies 54(3 \& 4), 603-622.

Snodgrass, K.R., 2008, Stories of intent. A comprehensive guide to the parables of Jesus, Eerdmans, Grand Rapids/Cambridge.

Swinton, J. \& Mowat, H., 2006, Practical theology and qualitative research, SCM Press, London.

Van Aarde, A.G., 1994, 'The historical-critical classification of Jesus' parables and the metaphoric narration of the wedding feast in Matthew 22:1-14', in God-with-us: The dominant perspective in Matthew's story, and other essays, pp. 229-247, Gutenburg, Pretoria. [HTS Teologiese Studies/Theological Studies, suppl. 5].

Van Aarde, A.G., 2008, "'Op aarde net soos in die hemel":Mattheus se eskatologie as die koninkryk van die hemel wat reeds begin kom het', HTS Teologiese Studies/ Theological Studies 64(1), 529-565. http://dx.doi.org/10.4102/hts.v64i1.30

Van der Horst, P. (ed.), 2003, Persuasion and dissuasion in early Christianity, Ancient Judaism, and Hellenism. Peeters, Leuven.

Van der Ven, J.A., 1998, Formation of the moral self, Eerdmans, Grand Rapids/ Michigan.

Van der Ven, J.A., 2010, Opnieuw naar de Areopaag. Over de uitoefening van het recht op godsdienstvrijheid in de publieke arena, Radboud Uiversiteit Nijmegen, Nijmegen.

Vorster, J.N., 1994, 'The epistemic status of rhetoric', Neotestamentica 28(2), 469493.

Vorster, J., 2009, 'Rhetorical criticism', in A. du Toit (ed.), Focusing on the message. New Testament hermeneutics, exegesis and methods, pp. 505-578, Protea, Pretoria.

Vos, C.J.A., 1996, Die volheid daarvan, vol. 2, Human Sciences Research Council, Pretoria.

Weren, W.J.C., 1979, De broeders van den Mensenzoon: Mt.25, 31-46 als toegang tot de eschatologie van Mattheüs, Ton Bolland, Amsterdam. 